\title{
Social Vulnerability of Rural Dwellers to Climate Variability: Akwa Ibom State, Nigeria
}

\author{
Jemimah Timothy Ekanem and Idongesit Michael Umoh
}

\section{Contents}

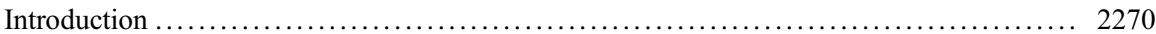

Rural Population Characterization in Akwa Ibom State .......................... 2273

Social Vulnerability of Rural Dwellers to Climate Variation in Akwa Ibom State ......... 2275

Factors Affecting Social Vulnerability to Climate Variation ........................ 2281

Empirically Defining the Underlying Dimensions of Factors Affecting Social

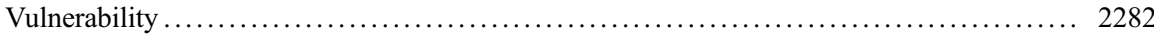

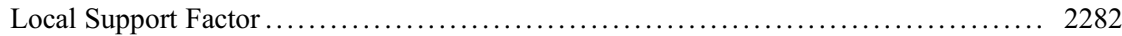

Educational Challenge Factor ......................................... 2283

Income /Employment/Replacement Ability Factor .............................. 2283

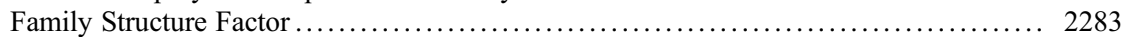

Demographic Explosion Factor ......................................... 2283

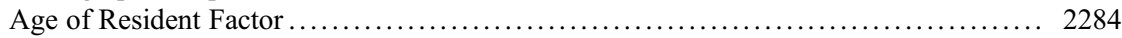

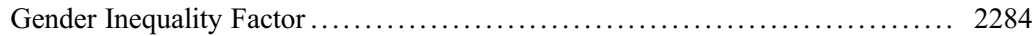

Tribal Issues, Public Assault and Insecurity Factor ..................... 2284

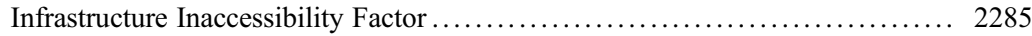

Loss of Properties/ Accommodation Factor ........................... 2285

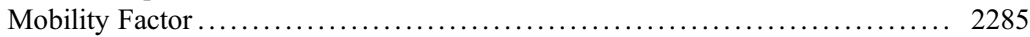

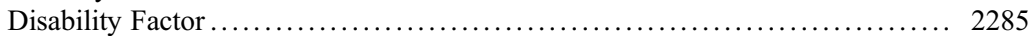

Weak Local Institution Factor .................................... 2286

Cultural Constraints Factor ...................................... 2286

Climate Information/ Communication Factor .......................... 2286

This chapter was previously published non-open access with exclusive rights reserved by the Publisher. It has been changed retrospectively to open access under a CC BY 4.0 license and the copyright holder is "The Author(s)". For further details, please see the license information at the end of the chapter.

J. T. Ekanem ( $\square)$

Department of Agricultural Economics and Extension, Faculty of Agriculture, Akwa Ibom State University, Uyo, Nigeria

e-mail: jemimahekanem@aksu.edu.ng

I. M. Umoh

Agricultural Science Education Unit, Department of Science, Redemption Academy, Uyo, Nigeria 
Loosed Social Network and Safety Net Factor ....................... 2286

Environmental / Social Discrimination Factor ........................... 2287

Measures to Reduce Rural Residents' Social Vulnerability to Climate Change ... 2287

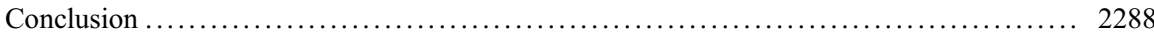

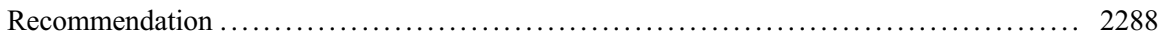

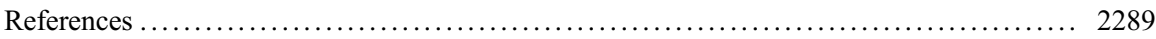

\section{Abstract}

For their livelihood activities, rural farming communities depend more on extractive capital. Their capacity to cultivate sufficiently for their family maintenance is greatly impeded by the absence of either temperature or rainfall quantity pattern or uniformity. The divergent effects of recent extreme weather events around the world, including within relatively small geographical areas, exemplify the unequal impacts of climate change on populations. Akwa Ibom State has been found vulnerable to extreme weather events, such as flooding, severe storms, and rising sea levels, leading to homelessness, poverty, conflicts, and war for millions of people. All of these have resulted in social disturbances and dislocations among rural populations, especially in coastal communities, making them more vulnerable to climate variability. In the field of social vulnerability in the state, not much has been achieved. This chapter analyzes the vulnerability of the rural population to climate variability; the socio-economic characteristics of the rural population; the index of social vulnerability of rural dwellers to climate variability; social vulnerability factors; and the rural population's social vulnerability mitigation initiatives in Akwa Ibom State, Nigeria. Social science approaches to human vulnerability draw critical attention to the root causes and factors why people are forced to respond to risks from climate change. A complex social approach to vulnerability is most likely to enhance mitigation and adaptation preparation efforts, given that vulnerability is a multidimensional mechanism rather than an invariable state.

\section{Introduction}

Reading through Gallent and Scott's (2017) observations on rural development planning, it gives a great deal of concern and experience that rural planning has been reduced to the least topic of planning theory and practice in more than five decades. A topical issue of rural development planning in the developing countries of the world should be the improvement of the economy at the rural governance level, given that the area is abundantly endowed with human and natural resources. The vast majority of the population still resides in rural areas and depends on the area for food as well as the supply of basic industrial raw materials, regardless of the increased rural-urban migration rate in many developing countries, including Nigeria (UN 2018).

A 2018 United Nations report showed that a quarter of the population in the countries of the Organization for Economic Co-operation and Development (OECD) is mainly rural, while the rural population is $46 \%$ worldwide. Critically, the rural economy is characterized by its own people, cultural characteristics, the uniqueness 
of the natural resource base, social and political institutions, and a combination of rural life which promotes national development. Eighty percent of the population in Nigeria lives in rural areas and their livelihoods are essentially linked to the rural economy (Ering et al. 2014). In addition, the rural area is described as having a low population density, small geographical sizes, and relative isolation, where people are relatively homogeneous in their values, norms, customs, and culture (Ebong 2017). Ejue emphasized that Nigeria's rural areas are characterized by poor and dilapidated roads, inadequate health facilities, inadequate and poorly equipped educational facilities, poor social facilities, high levels of poverty, unplanned residential layout, and other bottlenecks that hinder human well-being.

Notwithstanding these negative aspects, Scott et al. (2019) found that the rural area can be a reservoir of potential such as serene environment, quality land mass, rich biodiversity, tourism entertainment sites, and indigenous local knowledge reservoirs. At the rudimentary level, Frank and Hibbard (2017) also noted that rural areas provide the backdrop for a number of critical planning issues, such as the distribution of renewable energy, the management and improvement of biodiversity services, food production and security, as well as the extraction and administration of natural resources.

Rural people live very closely with nature in rural areas and natural resources provide the basis from which their fundamental needs are derived. Most of the population in rural regions, for example, rely on rain to start farming activities. There is a unique ecosystem for every community in the rural area, valued, admired, and protected by the people living there. For their social, spiritual, and economic development, they rely on those resources. However, due to prevailing climate conditions and associated events such as floods, storms, droughts, and landslides, a good number of rural dwellers are dislocated, especially in the coastal regions (Gallent et al. 2017). For example, some households are known to have moved further inland from their original settlements in Akwa Ibom State, a southern Nigerian state, leading to geographical dislocations (Ebong 2017). In coastal regions, displacement and migration of people from and to different settlements has also been linked to either or both the incidence of drought and accelerated sealevel rise (Abaje et al. 2016). Developing countries are projected to have an uneven share of the impact of climate variability, and due to its geography, climate, vegetation, soils, population and settlement, energy demand, and agricultural activities, Nigeria is particularly vulnerable (Abaje et al. 2016).

Via extremes of weather and interannual fluctuations, climate situations influence both natural and social processes. In some rural areas, with drenching downpour, the capacity of rural households to generate enough to feed themselves is greatly impeded by short rainy seasons (Okpara et al. 2017). These weather patterns influence agricultural production, reduce crop yields, and, in response to the prevailing conditions, enable farmers to change their agricultural practices. In the work of Umoh et al. (2013), it was reported that Akwa Ibom State was vulnerable to adverse impacts of climate variability and change in the Niger Delta region of Nigeria. Considering the widespread poverty, unequal distribution of land, over reliance on rain-fed agriculture, low income, and poor institutional capability, this observation became evident. The State is also vulnerable to extreme 
weather events such as flooding, severe storms and rising sea levels, in addition to inter-seasonal and inter-annual climate variations, resulting in loss of food crops, household food shortages, homelessness, poverty, and exacerbating circumstances that would lead millions of people to violence, war, and misery (Umoh et al. 2013). In some communities in Akwa Ibom State, heavy and sustained rainfall beyond the absorption capacity of the soil and the flow capacity of rivers and streams is prevalent, and populated areas adjacent to these rivers and streams are subject to recurring flooding, making the region "flood-prone" and placing the population at risk. All of these contribute to social disruption and dislocation of rural populations, especially in coastal communities, making them more vulnerable to climate change.

There is really no consensus that the exact nature of vulnerability renders it a relative concept that is disputed. The word "vulnerability" is derived from a Latin word meaning to be hurt, "vulnerare." This demonstrates the vulnerability of persons and activities to physical violence and/or psychological harm. The vulnerability of a device, individual, or person to a threat is broadly related to the potential to be harmed by that threat (Calderon and Serven 2014). The Intergovernmental Panel on Climate Change (IPCC) describes vulnerability as "the degree to which a system, including climate instability and extremes, is vulnerable to or incapable of dealing with adverse effects of climate change" (IPCC 2014). Vulnerability can have some effect on physical and socio-economic characteristics that are not static. This implies that vulnerability is unique to those evaluating it in a place, context, time, and perspective. Social scientists and climate scientists also use the word "vulnerability" to mean various things, although social scientists prefer to see vulnerability as reflecting the collection of socio-economic factors that decide the capacity of people to cope with stress or change, allowing groups to differ (Allen 2011; Huynh and Stringer 2018). Climate scientists also view a human system's vulnerability as determined by the existence of the physical hazards to which it is exposed, the probability of the hazards occurring regularly and the level of human exposure to hazards, as well as the resilience of the systems to the danger impacts (Ruppert and Deady 2017; Sadri et al. 2017). Vulnerability, therefore, is a combined hazard, exposure, and sensitivity feature (Calderon and Serven 2014).

Most commonly, social vulnerability is described as "the differential ability of groups and individuals to cope with hazards based on their physical and social world roles" (Dow 1992) or as "the inability to take effective loss insurance steps" (Bogard 1989). This also indicates the degree to which the loss, injury, or harm caused by the effects of a climate threat is revealed to a population, physical infrastructure, economic assets, and the general well-being of individuals. Any of these consequences are due to the features of social relationships, organizations and structures, and cultural values. In contrast to the prevailing belief in vulnerability to the impacts of climate variation, which focuses on the physical dimensions, this concept draws more attention to the social dimension of vulnerability. Obviously, social vulnerability focuses on demographic, social, economic, political, and cultural factors that increase the effect of climate hazards on rural inhabitants. In terms of education, gender, income, health status, access to credit and information technology, formal and informal (social) capital, 
political power, and so on, people living in a group most often differ; these variables also trigger variations in their levels of vulnerability (Huynh and Stringer 2018).

Unfortunately, the social dimensions of vulnerability to climate hazards are rarely paid attention to in most recorded issues and corresponding measures, thus explaining the reason for the very limited studies on social vulnerability in Nigeria taken either at national or state level. In the disaster literature, social insecurity of people in rural areas is widely overlooked and tends to be the least documented condition, explaining why social losses are most frequently missing in estimates of postdisaster cost/loss assessment (White and Howe 2012; UN 2018). Not being able to assess all aspects of climate-related vulnerability would have a detrimental effect on the adaptability of populations and their resilience to climate-related risks. There has been a strong gap in the actual understanding of how socially vulnerable rural communities in Akwa Ibom State emphasize the need to assess their status as socially vulnerable to climate change, taking into account steps to mitigate social vulnerability in rural communities. In order to fill the void, this research came in.

Therefore, this chapter summarizes the report of a state-run study on the social vulnerability of rural dwellers to climate variability. The study described the rural population in the state as specific targets, identified the social vulnerability index of the rural population in the state, identified factors affecting the social vulnerability of the rural population in the state, and identified initiatives to reduce the social vulnerability of the rural population in the state.

\section{Rural Population Characterization in Akwa Ibom State}

Sex, marital status, age, educational qualification, primary occupation, monthly income, household size, form of housing, position of building, and health status were the selected socio-economic characteristics of the respondents considered in the sample. The respondents' sex distribution showed that there were more females in the areas than males. The dominance of women in the fields of study can be attributed to the migration of men to the source of alternative opportunities for urban jobs. It also means that with climate change, more women are likely to be affected because in the study region they outnumbered the men. During rehabilitation, women will have more difficult times than men, due to streamlined jobs, meager salaries, and responsibility for family care. In local and national decision-making, women often lack a voice and a representative and are isolated in political processes, affecting their exposure, sensitivity, and resistance to climate hazards (Mansur et al. 2016; Anderson 2014).

Women account for the greater majority of the world's poor in rural areas. They depend on natural resources for their livelihoods and survival more than men. Women tend to have lower earnings and are more likely than men to be economically dependent. For example, when droughts or unseasonable rains threaten agricultural production, men may use their savings and economic freedom to invest in or otherwise adapt to alternative sources of income (Omi and Winant 2015). But as household shock absorbers during periods of economic and physical deprivation, women extend 
their already highly undervalued working hours and may even decrease their nutritional status to increase that of the family (Maldonado et al. 2016).

The majority of respondents were married during the research. The high percentage of married respondents is consistent with Ekanem et al. (2020), who noted that among rural people in Nigeria, getting married is highly valued with the intention of using these women for unpaid family work. The high percentage of "married" marital status appears to impose certain restrictions on most female study respondents because married women are forced to adhere to certain requirements imposed by their husbands directly or indirectly by tradition. Men's dominant efforts make women feel inferior and unable to take part in life-affecting events. For example, a female respondent said, "When disaster occurs, without the consent of our husbands, we cannot move."

In the research area, the study found a certain percentage of widowed respondents. This may be attributed to a high mortality rate among men drowning in the high seas during an expedition to fish in the coastal parts of the state. During the analysis, the percentage of the separated according to the extracts from the FGD groups is due to the loss of housing during the flood time that makes couples absolutely powerless as they have to transfer to nonaffected areas. One of the women had to say, "Our husbands migrate from rural areas to cities to exploit perceived economic opportunities in the course of economic deprivation as migrants and indirectly dumb us at home to take care of children, elderly or sick family members and often remarry other women outside our culture."

The bulk of the respondents were between the ages of 61-80. Because of their health problems, those respondents who were within the age range of 60-80 years were considered to be economically inactive, rendering them unable to embrace new information or to engage in adaptation preparation in order to minimize their degree of social vulnerability to climate change. The educational level of rural residents can restrict their ability to understand and respond to climate information. The findings of our study showed that the majority of respondents $(64.7 \%)$ did not have formal education, $23.7 \%$ had primary education, $11.0 \%$ had secondary education, while just $0.67 \%$ of respondents read up to tertiary level. This means that the majority $(64.7 \%)$ of respondents would be more vulnerable to climate change due to their inability to access, read, and comprehend weather information literature, as posited by Davies et al. (2017), who noted that various climate threat information cannot be accessed or acted upon by the least informed community members in order to plan for recovery.

The majority of respondents had agriculture as their primary occupation, with few others taking on employment in commerce, crafts, and wages. Other occupations, such as boat mending, water transport, motorcycling, etc., constituted $1.7 \%$ of the primary occupation of the respondents. The outcome showed that $40.0 \%$ of the respondents were artisans engaged in various low-income activities. During catastrophes, this behavior is typically lost and therefore increases their vulnerability and resilience.

Most respondents had a monthly income of N1,000-20,000, with just $1 \%$ of respondents receiving a monthly income of N40,001-N60,000. The outcome 
indicates that $95 \%$ of low-income $(1000-20,000)$ respondents had little to no financial support to mitigate their social vulnerability. Ekanem et al. (2020) and Anderson (2014) expressed the view that households with less access to energy are more economically sensitive to the impacts of immediate and eventual climate variability.

Household sizes are very high for rural dwellers in Akwa Ibom State. Our study found that most respondents had household sizes in the range of 11-15 individuals. Due to frequent flooding that damages residential apartments causing population displacement, it can be deduced that household size increases, which could result in more individuals sharing few habitable apartments. Some respondents, especially the coastal residents, pointed out that "we lost our houses when disaster hits and plead with neighbors to squat us." The standard of the housing is closely linked to the personal wealth of the respondent. That is why some rural residents live in badly developed houses that are vulnerable to heavy rainstorms and flooding (Hollesen et al. 2018). Our analysis has revealed 79. Nine percent of the respondents lived in thatched roof mud buildings, while $8.3 \%, 5.7 \%$, and $6.3 \%$ of the respondents lived in zinc roof, zinc mud, and zinc cement, respectively. As Cutter et al. (2016) and Kintisch (2016) asserted that rural poor live in substandard and overcrowded houses vulnerable to the spread of diseases and the effect of disasters, the results indicate that respondents are mostly poor. Of necessity, this is a vital element in assessing the vulnerability of climate hazards. In rural areas, the value, quality, and density of residential buildings affect possible losses and recovery.

Observations have shown that, as demonstrated by the 2009 U.S. Hurricanes Katrina, climate threat and its aftermath have a significant effect on people with disabilities. Our analysis found that $19.9 \%$ of the participants were people with disabilities. These individuals are likely to be more vulnerable to the consequences of climate variability as "climate change causes increasing distress and reduced opportunities for them to access critical emergency information" (Cutter et al. 2016; Hollesen et al. 2018). The World Report on Disability also reveals that people with disabilities are particularly inclined to be neglected in emergency assistance and relief operations (World Health Organization and World Bank 2011) (Table 1).

\section{Social Vulnerability of Rural Dwellers to Climate Variation in Akwa Ibom State}

Table 2 indicates many factors that predispose households to the adverse effects of the state's climate variability. Ten elevated rank variables have been picked. The first three reasons were: dwelling place loss $(\mathrm{x}=2.38$; ranked 1$)$, properties open to criminals $(\mathrm{x}=2.32$; ranked 2$)$, and children's failure to complete their education $(\mathrm{x}=2.29$; ranked 3$)$. The results suggest that the nature and location of housing makes individuals more vulnerable to risks. In hazard-prone areas, such as flood plains and slums, poor people are more likely to live. This 
Table 1 Distribution of rural dwellers based on their socio-economic characteristics

\begin{tabular}{|c|c|c|c|}
\hline Item & Selected variables & $\begin{array}{l}\text { Frequency } \\
\mathrm{n}=300\end{array}$ & $\begin{array}{l}\text { Percentage } \\
(\%)\end{array}$ \\
\hline \multirow[t]{2}{*}{1} & Sex & & \\
\hline & $\begin{array}{l}\text { Male } \\
\text { Female }\end{array}$ & $\begin{array}{l}142 \\
158\end{array}$ & $\begin{array}{l}47.3 \\
52.7\end{array}$ \\
\hline \multirow[t]{2}{*}{2} & Marital status & & \\
\hline & $\begin{array}{l}\text { Single } \\
\text { Married } \\
\text { Separated } \\
\text { Widowed }\end{array}$ & $\begin{array}{l}33 \\
150 \\
27 \\
90\end{array}$ & $\begin{array}{l}11.0 \\
50.0 \\
9.0 \\
30.0\end{array}$ \\
\hline \multirow[t]{2}{*}{3} & Age (years) & & \\
\hline & $\begin{array}{l}<1-20 \\
21-40 \\
41-60 \\
60-80\end{array}$ & $\begin{array}{l}1 \\
3 \\
50 \\
240\end{array}$ & $\begin{array}{l}0.3 \\
1.0 \\
18.7 \\
80.0\end{array}$ \\
\hline \multirow[t]{2}{*}{4} & $\begin{array}{l}\text { Educational status (years of formal } \\
\text { schooling) }\end{array}$ & & \\
\hline & $\begin{array}{l}0 \\
1-4 \\
5-8 \\
9-12 \\
\end{array}$ & $\begin{array}{l}194 \\
71 \\
33 \\
2\end{array}$ & $\begin{array}{l}64.7 \\
23.7 \\
11.0 \\
0.67\end{array}$ \\
\hline \multirow[t]{2}{*}{5} & Primary occupation & & \\
\hline & $\begin{array}{l}\text { Farming } \\
\text { Trading } \\
\text { Artisan } \\
\text { Salaried job } \\
\text { Others (Ukada) }\end{array}$ & $\begin{array}{l}66 \\
88 \\
120 \\
21 \\
5\end{array}$ & $\begin{array}{l}22.0 \\
29.3 \\
40.0 \\
7.0 \\
1.7\end{array}$ \\
\hline \multirow[t]{2}{*}{6} & Income level (N) & & \\
\hline & $\begin{array}{l}<1-20,000 \\
20,001-40,000 \\
40,001-60,000 \\
60,001-80,000\end{array}$ & $\begin{array}{l}289 \\
9 \\
4 \\
1\end{array}$ & $\begin{array}{l}95.3 \\
3.0 \\
1.3 \\
0.3\end{array}$ \\
\hline \multirow[t]{2}{*}{7} & Household size & & \\
\hline & $\begin{array}{l}1-5 \\
6-10 \\
11-15\end{array}$ & $\begin{array}{l}27 \\
115 \\
158\end{array}$ & $\begin{array}{l}9.0 \\
38.3 \\
52.7\end{array}$ \\
\hline \multirow[t]{2}{*}{8} & Housing type & & \\
\hline & $\begin{array}{l}\text { Thatch roof } \\
\text { Zinc roof } \\
\text { Mud with zinc } \\
\text { Cement with zinc }\end{array}$ & $\begin{array}{l}239 \\
25 \\
17 \\
19\end{array}$ & $\begin{array}{l}79.7 \\
8.3 \\
6.3 \\
6.3\end{array}$ \\
\hline \multirow[t]{2}{*}{9} & Location of building & & \\
\hline & $\begin{array}{l}\text { Low lying land } \\
\text { Flood plain } \\
\text { Close to seashore } \\
\text { Upland }\end{array}$ & $\begin{array}{l}15 \\
19 \\
56 \\
210\end{array}$ & $\begin{array}{l}5.0 \\
6.3 \\
18.7 \\
70.0\end{array}$ \\
\hline
\end{tabular}


Table 1 (continued)

\begin{tabular}{l|l|l|l}
\hline \multirow{2}{*}{ Item } & Selected variables & $\begin{array}{l}\text { Frequency } \\
\mathrm{n}=300\end{array}$ & $\begin{array}{l}\text { Percentage } \\
(\%)\end{array}$ \\
\hline $\mathbf{1 0}$ & Health status & & \\
\cline { 2 - 4 } & Not physically challenged & 240 & 80.0 \\
& Hearing/speech impaired & 12 & 4.0 \\
& Visually impaired & 19 & 6.3 \\
& Amputated & 8 & 2.6 \\
& Hypertensive/diabetic patient & 21 & 7.0 \\
\hline
\end{tabular}

corroborates the earlier findings of Birkmann (2013) and Nelson et al. (2016), who recorded that hastily established settlements are more physically vulnerable in terms of subsistence and geographical position to immediate climate impacts. Nelson et al. (2016) further clarified that rural communities have less political voice in disasters such as severe flooding and windstorms, thus raising the likelihood of their residents being physically harmed. Brown (2016) argued that the most vulnerable to climate hazards are likely to be the least trained and low-skilled members of society and that government may pay little attention to their well-being. This implies, as Tall (2019) notes, that vulnerability is reduced by better education and knowledge. Suitable weather knowledge, for example, enables farmers to predict seasonal trends.

Variables in the 4 th, 5 th, and 6 th ranks were loss of privacy $(x=2.27)$, blocked from health facilities $(x=2.20)$, local workshop destruction $(x=2.18)$. During floods, the privacy of people tends to be absolutely threatened, eventually subjecting them to immense social deprivation. The women had this to say in the study area (coastal region); in many cases, due to lack of privacy, we cannot respond to the call of nature. As a consequence, to defecate, we have to wait till night. In the case of pregnant mothers, disabled, and elderly people, the condition is getting worse. The study by Brondizio et al. (2016) and Hollesen et al. (2018) reinforced that during floods, disease outbreaks are prevalent; they submerge latrines and contribute to misery. They not only become victims of snake bites, but also suffer from skin diseases regularly. People in poor health and those who are undernourished will be more vulnerable to the immediate and secondary effects of extreme climate events, according to Hardy et al. (2017), since they are less likely to be able to plan for or cope with the impacts of climate hazards.

The ranked variables placed 7th, 8th, 9th, and 10th were: absence of services $(x=2.16)$, evaluation of relief materials $(x=2.15)$, loss of relatives $(x=2.11)$, and lack of drinking water $(x=2.10)$. These results have reinforced the assertions of Gamble et al. (2010), who identified the need to take into account the role of human and social capital in assessing climate impact vulnerability. They believed that human and social resources can contribute to the capacity of a society to overcome climate variability through coping and response capacities, whereas a lack of capital can leave individuals isolated and at higher risk of impacts such as severe heat waves being revealed. 
Table 2 Social vulnerability of rural dwellers to climate variability

\begin{tabular}{|c|c|c|c|c|c|c|c|}
\hline $\mathrm{S} / \mathrm{N}$ & Statements & SD & $\mathrm{D}$ & A & SA & Mean & Rank \\
\hline 1 & $\begin{array}{l}\text { We hardly see } \\
\text { our relatives as } \\
\text { they have been } \\
\text { dislocated } \\
\text { because of } \\
\text { constant flood }\end{array}$ & $33(11.0)$ & $72(24.0)$ & $103(34.3)$ & $92(30.7)$ & 2.1 & 9 \\
\hline 2 & $\begin{array}{l}\text { Our local } \\
\text { workshop has } \\
\text { been destroyed } \\
\text { by constant } \\
\text { flooding }\end{array}$ & $18(6.0)$ & $110(36.7)$ & $111(37.0)$ & $61(20.3)$ & 2.18 & 6 \\
\hline 3 & $\begin{array}{l}\text { Peoples' houses } \\
\text { are pulled down } \\
\text { by strong wind } \\
\text { in my } \\
\text { community }\end{array}$ & $5(1.7)$ & $99(33.0)$ & $108(3.0)$ & $88(29.3)$ & 1.90 & 15 \\
\hline 4 & $\begin{array}{l}\text { There is no safe } \\
\text { drinking waters } \\
\text { in my } \\
\text { community as a } \\
\text { result of flood }\end{array}$ & $44(14.7)$ & $48(38(12.7)$ & $113(373)$ & $95(31.7)$ & 2.10 & 10 \\
\hline 5 & $\begin{array}{l}\text { People lost their } \\
\text { homes due to } \\
\text { severe storm }\end{array}$ & $5(1.7)$ & $38(12.7)$ & $94(31.3)$ & $163(54.3)$ & 2.38 & 1 \\
\hline 6 & $\begin{array}{l}\text { Our food crop } \\
\text { is lost because } \\
\text { of rise in water } \\
\text { level }\end{array}$ & $6(2.7)$ & $49(16.3)$ & $128(42.0)$ & $117(39.0)$ & 1.72 & 19 \\
\hline 7 & $\begin{array}{l}\text { Our children } \\
\text { cannot } \\
\text { complete their } \\
\text { education } \\
\text { because school } \\
\text { facilities are } \\
\text { flooded }\end{array}$ & $16(5.3)$ & $30(10.0)$ & $105(35.0)$ & $149(49.7)$ & 2.29 & 3 \\
\hline 8 & $\begin{array}{l}\text { People are } \\
\text { attack with } \\
\text { different } \\
\text { diseases such as } \\
\text { skin infection, } \\
\text { malaria, } \\
\text { typhoid, and } \\
\text { dysentery } \\
\text { because of } \\
\text { continuous } \\
\text { inflow of water }\end{array}$ & $70(23.3)$ & $32(10.7)$ & $69(23.0)$ & $129(43.0)$ & 1.86 & 16 \\
\hline
\end{tabular}

(continued) 
Table 2 (continued)

\begin{tabular}{|c|c|c|c|c|c|c|c|}
\hline $\mathrm{S} / \mathrm{N}$ & Statements & SD & $\mathrm{D}$ & A & SA & Mean & Rank \\
\hline 9 & $\begin{array}{l}\text { Our community } \\
\text { is blocked from } \\
\text { healthcare } \\
\text { services } \\
\text { because of } \\
\text { increase in } \\
\text { water level }\end{array}$ & $10(3.3)$ & $41(13.7)$ & $128(42.7)$ & $121(40.3)$ & 2.20 & 5 \\
\hline 10 & $\begin{array}{l}\text { We cannot } \\
\text { attend } \\
\text { ceremonies like } \\
\text { wedding child } \\
\text { dedication in } \\
\text { nearby } \\
\text { communities } \\
\text { due to high } \\
\text { level of water }\end{array}$ & $77(25.7)$ & $32(10.7)$ & $66(22.0)$ & $125(41.7)$ & 1.80 & 17 \\
\hline 11 & $\begin{array}{l}\text { Our properties } \\
\text { are open to } \\
\text { thieves because } \\
\text { of lack of } \\
\text { accommodation }\end{array}$ & $85(28.3)$ & $29(9.7)$ & $55(18.3)$ & $131(43.7)$ & 2.32 & 2 \\
\hline 12 & $\begin{array}{l}\text { We do not have } \\
\text { privacy where } \\
\text { we are } \\
\text { squatting }\end{array}$ & $52(17.3)$ & $97(32.3)$ & $48(160)$ & $154(51.3)$ & 2.27 & 4 \\
\hline 13 & $\begin{array}{l}\text { Our traditional } \\
\text { food and dialect } \\
\text { are } \\
\text { disappearing as } \\
\text { we move to } \\
\text { new } \\
\text { communities. }\end{array}$ & $21(7.0)$ & $30(10.0)$ & $44(14.7)$ & $112(37.3)$ & 1.79 & 18 \\
\hline 14 & $\begin{array}{l}\text { Our children } \\
\text { get involve in } \\
\text { hard jobs to } \\
\text { contribute to } \\
\text { family's } \\
\text { income }\end{array}$ & $31(10.3)$ & $113(37.7)$ & $36(12.0)$ & $171(57.0)$ & 2.03 & 11 \\
\hline 15 & $\begin{array}{l}\text { People with } \\
\text { disabilities } \\
\text { have lost } \\
\text { assistance and } \\
\text { care from } \\
\text { relatives as } \\
\text { flood disrupt } \\
\text { their dwelling } \\
\text { places }\end{array}$ & 29(9.) & $64(21.3)$ & $69(23.0)$ & $155(51.7)$ & 2.18 & 6 \\
\hline
\end{tabular}

(continued) 
Table 2 (continued)

\begin{tabular}{|c|c|c|c|c|c|c|c|}
\hline $\mathrm{S} / \mathrm{N}$ & Statements & SD & D & A & SA & Mean & Rank \\
\hline 16 & $\begin{array}{l}\text { There is } \\
\text { reduction in our } \\
\text { livestock } \\
\text { production as } \\
\text { floods pull } \\
\text { down } \\
\text { farmsteads }\end{array}$ & $25(8.3)$ & $51(17.0)$ & $89(29.0)$ & $136(45.3)$ & 1.71 & 20 \\
\hline 17 & $\begin{array}{l}\text { We cannot } \\
\text { recover our lost } \\
\text { properties }\end{array}$ & $28(9.3)$ & $47(15.7)$ & 111(37.0) & $98(32.7)$ & 1.93 & 14 \\
\hline 18 & $\begin{array}{l}\text { We lack } \\
\text { facilities to } \\
\text { reach out to our } \\
\text { customers to } \\
\text { sell our farm } \\
\text { produce }\end{array}$ & $29(9.7)$ & $62(20.7)$ & $122(40.0)$ & $106(35.3)$ & 2.16 & 7 \\
\hline 19 & $\begin{array}{l}\text { We are cut off } \\
\text { from } \\
\text { neighboring } \\
\text { community }\end{array}$ & $26(8.7)$ & $46(15.3)$ & $109(36.0)$ & $124(41.3)$ & 1.99 & 13 \\
\hline 20 & $\begin{array}{l}\text { We cannot } \\
\text { assess relief } \\
\text { materials in my } \\
\text { community }\end{array}$ & $26(8.7)$ & $41(13.7)$ & $99(33.0)$ & $120(40.0)$ & 2.15 & 8 \\
\hline 21 & $\begin{array}{l}\text { There is } \\
\text { scarcity of hired } \\
\text { or paid labor in } \\
\text { our community } \\
\text { due to } \\
\text { migration }\end{array}$ & $36(12.0)$ & $45(15.0)$ & $66(22.0)$ & $155(51.7)$ & 2.01 & 12 \\
\hline 22 & $\begin{array}{l}\text { Our traditional } \\
\text { rulers do not } \\
\text { inform } \\
\text { government } \\
\text { about our } \\
\text { situation }\end{array}$ & $31(10.3)$ & $48(16.0)$ & $97(32.3)$ & $103(34.3)$ & 1.67 & 21 \\
\hline
\end{tabular}

KEY

$\mathrm{SD}=$ Strongly Disagree

$\mathrm{D}=$ Disagree

$\mathrm{A}=$ Agree

$\mathrm{SA}=$ Strongly Agree

Rural dwellers seem vulnerable because they cannot access the services of their society to cope with climate change shocks and stresses. Hardy et al. (2017) argued that their choices are limited and very difficult for them to think beyond their immediate needs, let alone make adaptation plans, if people do not have secured 
access to vital livelihood tools. Climate change disrupts social relationships, undermining family bonds, and social ties with loved ones.

\section{Factors Affecting Social Vulnerability to Climate Variation}

Factor analysis was used to examine and identify the factors affecting social vulnerability to climate variation. Sixty (60) items were initially generated during the instrument construction phase to reflect the objective after which it was subjected to factor analysis using principal component approach. This was done to reduce the number of items to major and sizeable significant number of factors using Eigen value criterion of $\geq 1$ to select the underlying dimensions of the original 60 items.

The principal components method is an exact mathematical transformation of the original set of variables to a new set, with the later summarizing linear relationships exhibited in the data. The best linear combination of the variables gives the first component or factor of the variables. It means that this factor, more than any other, accounts for most of the variance or relationships observed in the data and hence is the best summary of the original data. The second component is similarly defined as the next best linear combination of the variables that would account for the relationships observed in the data after the effect of the first component or factor has been removed, provided both components are uncorrelated (orthogonal). Subsequent components are similarly defined until all the relationships or variance in the data have been accounted for. The factor can therefore be defined as:

$$
\mathrm{F}=\mathrm{aWA}+\mathrm{bwB} \pm \ldots \mathrm{kwK}
$$

where

$\mathrm{Fa}=$ factor $\mathrm{a}$, being the best linear combination of all the variable A-K aw-kw $=$ are weights attached to variables

$\mathrm{A}-\mathrm{K}=$ variables $\mathrm{A}-\mathrm{K}$

Other factors can be similarly defined, as explained earlier. When the factors are uncorrelated, they are said to be orthogonal and a variable " $a$ " in the original data can be defined as:

$$
\mathrm{Z}_{\mathrm{a}}=\mathrm{Wa}_{1} \mathrm{~F}_{1}+\mathrm{W}_{\mathrm{a} 2} \mathrm{~F}_{2}+\ldots+\mathrm{W}_{\mathrm{a} 2} \mathrm{~F}_{2}+\ldots+\mathrm{W}_{\mathrm{ak}} \mathrm{F}_{\mathrm{k}}
$$

where $\mathrm{Z}_{\mathrm{a}}=$ Variable $\mathrm{a}$ in standard score format (mean $=0$ and variance 1$), \mathrm{W}_{\mathrm{a} 1}$ to $\mathrm{W}_{\mathrm{ak}}=$ Weights (normally called factor loadings) attached to factors, and $\mathrm{F}_{1}$ $\mathrm{F}_{\mathrm{k}}=$ factors $\mathrm{I}-\mathrm{K}$. Formula 2 simply means that in factor analysis employing the principal components methods, a variable is viewed as the sum of weighted factors derived from the data. When the data is initially factored, the concern is more on the 
possibility of reducing the data to a smaller composite set of factors. At this stage, the factors may not make any meaning until they are rotated to a final solution.

\section{Empirically Defining the Underlying Dimensions of Factors Affecting Social Vulnerability}

Seventeen (17) composite factors were mutually exclusive on the basis of the result of factor analysis performed and major trends were produced. Table 3 introduces these variables and addresses them below:

\section{Local Support Factor}

Inability to access community services is an important aspect of social insecurity, as it relates to the way rural dwellers are categorized on the basis of their income, according to literature (Birkmann 2012). Factor 1 accounts for $21.7 \%$ of variance and this is high. This outcome coincides with Passel's 2005 study that poorer households (low class) are not able to access resources fairly due to social factors (economic and political processes) that are custodians of upper class or wealthier people.

Table 3 Major dimensions of social vulnerability to climate variability

\begin{tabular}{l|l|l|l|l}
\hline Factor & Names & $\begin{array}{l}\text { Eigen } \\
\text { values }\end{array}$ & $\begin{array}{l}\% \text { of } \\
\text { variance }\end{array}$ & $\begin{array}{l}\text { Cumulative } \\
\%\end{array}$ \\
\hline 1 & Lack of local support & 12.995 & 21.658 & 21.658 \\
\hline 2 & Knowledge barrier & 3.762 & 6.270 & 27.928 \\
\hline 3 & Income/employment/replacement ability & 2.581 & 4.302 & 32.230 \\
\hline 4 & Family structure & 2.333 & 3.888 & 36.118 \\
\hline 5 & Demographic explosion & 2.129 & 3.548 & 39.667 \\
\hline 6 & Age of residents & 1.851 & 3.085 & 42.751 \\
\hline 8 & Gender inequality & 1.710 & 2.849 & 45.601 \\
\hline 9 & Tribal issue/public assault and insecurity & 1.564 & 2.607 & 48.208 \\
\hline 10 & Infrastructure inaccessibility & 1.542 & 2.571 & 50.779 \\
\hline 11 & Loss of properties and accommodation & 1.494 & 2.490 & 53.268 \\
\hline 12 & Mobility & 1.407 & 2.346 & 55.614 \\
\hline 13 & Disability & 1.291 & 2.152 & 57.766 \\
\hline 14 & Weak local institution & 1.225 & 2.041 & 59.808 \\
\hline 15 & Cultural constraint & 1.194 & 1.991 & 61.798 \\
\hline 16 & Poor climate information/communication & 1.173 & 1.955 & 63.753 \\
\hline 17 & source & & & \\
\hline
\end{tabular}




\section{Educational Challenge Factor}

Training is related to socio-economic status and accounts for $6.2 \%$ of rural dwellers' heterogeneity. Noneducational achievement in the field of study makes community members vulnerable to climate danger because they lack the opportunity to grasp knowledge on warning and recovery. The outcome of the finding is consistent with Nelson et al. (2016), who stated that during floods, children's schooling is impaired as it is difficult to keep and attend classes under submerged conditions. The school appears to become the "front-line" flood shelter for displaced families anywhere the school building is not submerged. UNICEF (2011) confirms this finding by stating that children are forced out of school when natural disasters interrupt the educational system of the community, including teachers. The absence of experienced teachers and other main school staff is detrimental to the academic success of children.

\section{Income /Employment/Replacement Ability Factor}

Floods have a significant effect on the source of livelihoods, paralyze economic activities, deepen disparities in economic status, and access to sufficient food and services in the field of research. This explains the $4.3 \%$ difference between rural communities. The result supports Sultana (2017) who reported that when affected by a danger case, local individuals who are in primary extraction activities such as fishing, forestry, crop cultivation, and livestock rearing suffer great losses and are unable to rebuild their settlement.

\section{Family Structure Factor}

When tragedy occurs, large family size hinders evacuation and this impact increases social vulnerability. There is less time, resources, and energy for families caring for ill members to invest in activities that could minimize the impacts of external threats, help them recover from dangerous incidents, and be better prepared for them in the future. Sultana (2017) also acknowledges that members of large and dependent families - children under the age of 18, elderly and disabled members - need financial assistance, transportation, and disaster medical treatment, and these affect the resilience to risk recovery. This portion explains the variability of $3.8 \%$ among respondents.

\section{Demographic Explosion Factor}

Village habitation is adversely impacted by population migration and neighborhood disorder. When the flood effect of the community or household shifts to the nonaffected area, there is a population influx leading to an increased risk of disease and sanitation system contamination. This is corroborated by McLeman (2016), who 
stressed that high population increases outbreaks of disease due to individual proximity to each other and contamination of human waste water sources. Increasing population density increases vulnerability, particularly where the density is high, according to local respondents. Increased population density limited access to land and exacerbated pressure on natural resources during challenging times, respondents clarified. Indeed, population growth means that growing numbers of people are exposed to the impacts of climate variations and that more people have to share scarce resources (e.g., water and food). This explains the $3.5 \%$ difference between rural dwellers.

\section{Age of Resident Factor}

Age is strongly associated to social disadvantage and $3.0 \%$ of the difference is clarified. There is also a rise in health challenges as individuals grow older, and these are compounded during times of dislocation or loss of livelihood due to climate change. The result confirms Omi and Winant (2015), who reported that due to adverse effects of climate variability such as hearing impairment, cognitive difficulties, rise in blood pressure (hypertension), etc., the elderly population experiences different health problems. This affects their potential for disaster management and recovery. Brondizio et al. (2016) also argued that children cannot protect themselves during a disaster, particularly the youngest age group, because they lack the resources, skills, or life experiences required to cope effectively with the situation.

\section{Gender Inequality Factor}

2.8 percent of the observed variance is explained by this factor. Sex is a powerful factor illustrating the susceptibility to impacts related to climate change. Factors such as lack of access to and power over basic resources and lack of entitlements exacerbate the vulnerability of women and weaken their capacity to cope with disaster effects (Sultana 2014). The result is consistent with Brown (2016) which stated that because of their distinct socially constructed positions as mothers and family caregivers, women suffer more from the impact of disaster. Faber (2015) notes that stream dries up during extreme situations, for example, when natural water sources, and women have to travel longer distances daily on foot in search of drinking water. The report shows that pregnant and lactating mothers make up a large proportion of these women. Furthermore, he added that women enumerated their experiences during constant flooding over menstrual hygiene management, especially in the coastal zone, resulting in genital injury, bleeding, infections, and other complications.

\section{Tribal Issues, Public Assault and Insecurity Factor}

2.6 percent of the variance among respondents is explained by this factor. Literature indicates that people who lose their homes during floods are absolutely powerless as they travel out to non-affected areas without any source of income. They lose the physical social security they once enjoyed in their native villages in their new 
housing as migrants. This, in turn, puts them in different kinds of adverse social circumstances; young girls in constant danger of sexual abuse and attack from the boys and men of that group who take shelter on embankments. Professional gangs are also coerced into prostitution by young women, with offers of work elsewhere (Maldonado et al. 2016). The outcome also agrees with Dunning (2011), who noted that, for example, people who do not speak the language of their host group have trouble understanding and reacting to the warning and evacuation order

\section{Infrastructure Inaccessibility Factor}

$2.5 \%$ of the variance is explained by this factor. The outcome is consistent with Davies et al. (2017), who stressed that social deprivation is increased by inaccessibility to vital infrastructure such as highways, shelter, and telecommunication. $\mathrm{He}$ emphasized that poorly maintained local road networks rendered some roads impassable. The other part of the city, including the economy, is cut off and blocked from some areas that would promote income security.

\section{Loss of Properties/ Accommodation Factor}

This factor explains $2.4 \%$ of the difference in rural populations. The outcome is in line with Brondizio et al. (2016) who highlighted the flood "sweep off" farmland leading to crop and income loss. In particular, thatch houses are said to be damaged in coastal communities by floods in the upland or sea level buildings. He further claimed that, especially for poor households, loss of property is more difficult to replace. Some fishermen describe their bitter experiences during a sea pirate attack fishing trip on the high seas where their boat engines and other instruments are stolen and destroyed.

\section{Mobility Factor}

This portion explains the variation among respondents of $2.3 \%$. The outcome of the results agrees with Cutter et al. (2016) who posited that for people who do not have cars, transport out of the evacuation zone is problematic. In coastal regions, the movement of people is distorted by the increase in sea level because canoes made locally cannot be paddled at high sea level, are victims of water-related diseases, and cannot access medical facilities and workers in upland areas leading to trauma of nonpathogenic hypertension and stroke conditions. Brown (2016) claims that when emergency strikes, people with disabilities have mobility restrictions, they have trouble finding safe places.

\section{Disability Factor}

This variable explains the difference of $2.2 \%$ among rural dwellers. The finding is synonymous with the World Disability Study (2011) that when emergency strikes, people with disabilities are left behind in a deteriorated community and are isolated from their families and friends, leading to crippling suffering on them, and they lack the social networks needed to take advantage of services that would speed up their disaster recovery. Hollesen et al. (2018) reported that disasters and their effects have a significant effect on people with disabilities due to the lack of assistive devices such as wheelchairs, crutches, white canes, or hearing aids. 


\section{Weak Local Institution Factor}

$2.0 \%$ of the differences among local dwellers are explained by this factor. Poor or corrupt institutions can contribute to ineffective and insufficient responses to disaster situations, slowing requests for government support and not actually delivering help to those most in need. This supports Ejue, who claimed that rural communities are limited by weak leadership and lack of freedom and decision-making power as their voices, needs, and desires are not integrated into government projects and this increases sensitivity for poorer households.

\section{Cultural Constraints Factor}

This element explains the variance of $1.99 \%$. The result is the same with Ejue, who argued that the lack of traditional wisdom has caused elders to suffer contempt from the younger generation because the wisdom they carry is not as detailed as it used to be. This outcome also agrees with Mansur et al. (2016), who stated that as their ethnic cultural identity suffers from the risks of extinction as a result of climaterelated risks, older people become more dissatisfied.

\section{Climate Information/ Communication Factor}

The lack of available, affordable, and appropriate sources of knowledge leads to social vulnerability. This explains $1.95 \%$ of the variance. It was found that respondents rely on their personal weather observation, past experience in their community and local institution due to irregularities, and untimely distribution of advance media information that they caption "false stories" or "fly news." Their conviction is due to the fact that localities are not subject to weather predictions from radio and NTA stations. This result is consistent with d'Alpoim et al. (2016), which posits that in terms of reliability, timing, and languages, there are shortcomings in the knowledge distribution process. It is important to communicate, obtain, and interpret information about weather forecasts and climate predictions via multiple channels, including interpersonal contact, television, radio, the Internet, and social media (Morss et al. 2017). Before they make decisions, individuals combine data from these different sources (Sadri et al. 2017). Social networks help people access, personalize, and understand the importance of knowledge in a significant way.

\section{Loosed Social Network and Safety Net Factor}

1.78 percent of the variance is explained by this factor. The study agrees with Cutter et al. (2016) that it is difficult for displaced populations to re-organize and restore their former family connections and relationships. Some respondents share their feelings that floods are hindering social activities such as marriage, commitment to children, and funerals. This condition weakens social capital and loosens social relations with loved ones, causing the respondents to be mentally depressed. Kintisch (2016) argued that the loss of the network and lack of access to social gathering make people feel lonely, especially the elderly. Meanwhile, Davies et al. (2017) assume that if placed in place, the social security net will help prevent 
postdisaster starvation and assist affected households and communities to safeguard and restore their properties.

\section{Environmental / Social Discrimination Factor}

This element explains the variance of $1.75 \%$. The outcome agrees with Cutter et al. (2016) and McDowell et al. (2016), who observed that a nation's inhabitants do not share the benefits of economic growth equally. Discrimination and social isolation result in this. And in rural areas, this is also true.

\section{Measures to Reduce Rural Residents' Social Vulnerability to Climate Change}

Table 3 demonstrates strategies that will reduce the social vulnerability of respondents in the study region to climate change. Ten of the most relevant high-rank indicators were chosen. The first four steps to mitigate social vulnerability to the effects of climate variation were: dam construction $(\mathrm{x}=3.62$; ranked 1$)$, flood storage reservoir construction ( $\mathrm{x}=3.57$; ranked 2), dam and bridge construction $(\mathrm{x}=3.56$; ranked 3$)$, and gutter opening $(x=3.54$; ranked 4$)$. These initiatives agree with Eriksen (2012), who noted that one of the adaptation techniques widely practiced by flood victims is the construction of defensive outlets such as flood storage reservoirs, dams, and water transport channels from the affected areas. Davies et al. (2017) accept that for uprooted communities, the embankment acts as temporary shelter.

The fifth method is working to fill sand bags in groups $(x=3.53$, ranked 5). This agrees with McDowell et al. (2016), who stated that for mutual benefit, societies with denser social support networks have more interaction between community members. Eriksen (2012) believed that societies with higher social and stronger social networks will be better able to cope with threats and their consequences because it is easier to analyze knowledge and other types of social support.

The sixth technique is the fund's payment $(\mathrm{x}=3.52$, ranked 6$)$. The results confirm that Huynh and Stringer (2018) emphasized that materials for relief and assistance are especially helpful to those individuals who could not afford to repair damaged properties themselves. The seventh, eighth, ninth, and tenth steps were: environmental law enforcement $(\mathrm{x}=3.50$, ranked 7), flood-prone areas should not be developed ( $\mathrm{x}=3.49$; ranked 8$)$, weather signal recognition $(\mathrm{x}=3.47$; ranked 9). The result corroborates the view of Omi and Winant (2015), who said that individuals should be prevented from developing areas vulnerable to flooding and that defaulters should be punished. And the use of local dialects $(\mathrm{x}=3.37$; rank 10). The results indicate that the combination of extension agents, radio, and local agencies will be more effective in disseminating local dialect environment information and supporting services in insecure areas for vulnerable people.

The least significant steps were: raising consciousness of income diversification $(\mathrm{x}=3.34$; ranked 11), building a well-equipped hospital $(\mathrm{x}=3.30$; ranked 12$)$, the proportion of local cultivars $(\mathrm{x}=3.02$ ranked 13$)$, and the lack of equitable access to local services $(\mathrm{x}=2.96$; ranked 14$)$. 


\section{Conclusion}

It can be inferred from the results obtained that $52 \%$ of women were vulnerable to climate change in rural areas of Akwa Ibom State. Most of the respondents were between 60 and 80 years of age. The majority of respondents (64\%) did not have formal education and are probably the least educated on climate issues. The most important steps to mitigate flooding from the perspective of the respondents were the construction of embankments, flood storage reservoirs, dams and bridges, and opening of gutters; and these were related to the position of respondent construction. The underlying dimensions affecting social vulnerability were lack of local support, information barrier, jobs, employment and replacement capability, family structure, demographic explosion, resident age factor, gender, tribal problems, public attack, and inaccessibility of infrastructure in the insecurity factor. Others included property and housing damages, mobility, disability, weak local institutions, cultural constraints; inadequate sources of environment knowledge and communication; loosened social networks and social security networks; and social discrimination. Rural residents in Akwa Ibom State were highly vulnerable to the effects of climate change because, as seen in the report, the higher the factors that lead to social vulnerability, the higher the degree of social vulnerability of the respondents.

\section{Recommendation}

The following recommendations are made based on the study's results and conclusions:

1. Agricultural extension staff, meteorological offices, and community-based agents should be assisted by policy makers and development partners to raise awareness of climate information forecasting and dissemination through usable and accessible communication methods such as local dialect radio, city critics, drama, newsletters, community workshops/seminars, and educational programs

2. Income diversification is an efficient way to reduce vulnerability by spreading risks. To minimize social vulnerability to extreme flooding and drought, less reliance on natural resources would help. Rural dwellers need to maintain and engage effectively in those value-added economic activities that will reduce food insecurity, increase jobs and income opportunities, and enable individuals to accumulate assets that will enhance their ability to cope with potential shocks without worsening poverty.

3. Adaptive planning is required to minimize the vulnerability of vulnerable coastal roads (ferry routes), low-lying buildings and assets, transport, and market connections and to improve legislation to safeguard hazard-prone areas. Adaptive planning is needed.

4. Local institutions should improve social capital, that is, family ties and friendly connections between members of the group should be revitalized so that individuals can collaborate and team up to resolve the effect and challenges of climate 
variations for mutual benefit among themselves. In the meantime, friendly ties with relatives away from home should be established for remittances to act as a cushion when subjected to extreme events and also for the provision of temporary accommodation during displacement.

\section{References}

Abaje IB, Sawa BA, Iguisi EO, Ibrahim AA (2016) Impacts of climate change and adaptation strategies in rural communities of Kaduna State, Nigeria. Ethiop J Environ Stud Manag 9(1): 97-108

Allen R (2011) Vulnerability reduction and the community-based approach. In: Pelling (ed) Natural disasters and development in a globaliing world. Routledge, London, pp 170-118

Anderson EN (2014) Caring for place: Ecology, ideology, and emotion in traditional landscape management. Walnut Creek, CA: Left Coast Press

Birkmann J (2012) Vulnerability reduction: a task for the vulnerable people themselves. In Bank off, et al (eds) Mapping vulnerability: disasters, development and Peter. Earthscan, Sterling

Birkmann J (2013) Measuring vulnerability to natural hazards: towards disaster resilient societies. United Nations University Press, Bonn

Bogard WC (1989) Bringing social theory to hazards research: conditions and consequences of the mitigation of environmental hazards. Sociol Perspect 31:147-168

Brondizio ES, de Lima AC, Schramski S, Adams C (2016) Social and health dimensions of climate change in the Amazon. Ann Hum Biol 43:405-414

Brown K (2016) Resilience, development and global change. Routledge, London/New York

Calderon C, Serven L (2014) Infrastructure, growth, and inequality: an overview. World Bank policy research working paper. The World Bank, Washington, DC

Cutter SL, Ash KD, Emrich CT (2016) Urban- rural differences in disaster resilience. Ann Am Assoc Geogr 106:1236-1252

d'Alpoim Guedes JA, Crabtree SA, Bocinsky RK, Kohler TA (2016) Twenty-first century approaches to ancient problems: climate and society. Proc Natl Acad Sci 113(51):14483-14491

Davies G, Frausin G, Parry L (2017) Are there food deserts in rainforest cities? Ann Am Assoc Geogr Adv. https://doi.org/10.1080/24694452.2016.1271307

Dow K (1992) Exploring differences in our common future(s): the meaning of vulnerability to global environmental change. Geoforum 23:417-436

Dunning MC (2011) Social vulnerability analysis methods for crops planning. Draft report 10/29/09

Ebong M (2017) Mobilisation of resources for rural development in Nigeria. Wusen Press, Calabar

Ekanem JT, Nwachukwu I, Umoh IM (2020) Post-harvest Adaptiveness of crop farmers to future climates in the Cross River floodplains, Nigeria. J Commun Commun Res 5(1):50

Eriksen SH (2012) Responding to global changes vulnerability and management of local agroecosystems in Kenya and Tanzania. University of East Anglia, Norwich

Ering SO, Otu JE, Archibong EP (2014) Rural Development Policies in Nigeria: A Critical Appraisal. Int J Educ Res 2(9):307-320

Faber JW (2015) Superstorm Sandy and the demographics of flood risk in New York City. Hum Ecol 43(3):363-378

Frank KI, Hibbard M (2017) Rural planning in the twenty-first century: context appropriate practices in a connected world. J Plan Educ Res 37(3):299-308

Gallent N, Scott M (eds) (2017) Rural planning and development. Routledge, London

Gallent N, Tewdwr-Jones M, Hamiduddin I (2017) A century of rural planning in England: a story of fragmentation, contestation and integration. Planum J Urban 35(2):91-104

Gamble DW, Campbell D, Allen TL, Barker D, Curtis S, Mcgregor D, Popke J (2010) Climate change, drought, and Jamaican agriculture: Local knowledge and the climate record. Annals of 
the Association of American Geographers 100:880-893. https://doi.org/10.1080/00045608. 2010.497122

Hardy RD, Milligan RA, Heynen N (2017) Racial coastal formation: the environmental injustice of colorblind adaptation planning for sea-level rise. Geoforum 87:62-72

Hollesen J, Callanan M, Dawson T, Fenger-Nielsen R, Friesen T, Jensen A, . . Rockman M (2018) Climate change and the deteriorating archaeological and environmental archives of the Arctic. Antiquity 92(363):573-586. https://doi.org/10.15184/aqy.2018.8

Huynh LTM, Stringer LC (2018) Multi-scale assessment of social vulnerability to climate change: an empirical study in coastal Vietnam. Clim Risk Manag 20(2018):165-180

IPCC (2014) Summary for policymakers. In: Field CB, Barros VR, Dokken DJ, Mach KJ, Mastrandrea MD, Bilir TE, White LL (eds) Climate change 2014: impacts, adaptation, and vulnerability. Contribution of working group II to the fifth assessment report of the Intergovernmental Panel on Climate Change. Cambridge University Press, Cambridge, UK/New York, pp 1-32

Kintisch E (2016) History is melting. Hakai Magazine. Retrieved from http://bit.ly/1PSoFxb

Maldonado J, Lazrus H, Bennett S-K, Chief K, Dhillon CM, Gough B, Whyte KP (2016) The story of rising voices: facilitating collaboration between indigenous and Western ways of knowing. In: Companion M, Chaiken M (eds) Responses to disasters and climate change: understanding vulnerability, building resilience. CRC Press/Taylor \& Francis Group, Boca Raton, pp 15-26

Mansur AV, Brondizio ES, Roy S, Hetrick S, Vogt ND, Newton A (2016) An assessment of urban vulnerability in the Amazon Delta and estuary: a multi-criterion index of flood exposure, socioeconomic conditions and infrastructure. Sustain Sci 11(4):625-643

McDowell G, Ford J, Jones J (2016) Community-level climate change vulnerability research: trends, progress, and future directions. Environ Res Lett 11(3):33001

McLeman R (2016) Impacts of population change on vulnerability and the capacity to adapt to climate change and variability: a typology based on lessons from "a hard country". Popul Environ 31:286-316

Morss R, Demuth J, Lazrus H, Palen L, Barton C, Davis C, ... Watts J (2017) Hazardous weather prediction and communication in the modern information environment. Bull Am Meteorol Soc 98(12):2653-2674

Nelson MC, Ingram SE, Dugmore AJ, Streeter R, Peeples MA, McGovern TH, ... Smiarowski K (2016) Climate challenges, vulnerabilities, and food security. Proc Natl Acad Sci 113(2): 298-303

Okpara UT, Stringer LC, Dougill AJ (2017) A novel climate - water conflict vulnerability index to capture double exposure: application in the Lake Chad Basin. Reg Environ Chang 17(2): $351-366$

Omi M, Winant H (2015) Racial formation in the United States, 3rd edn. Routledge, New York

Ruppert T, Deady EL (2017) Climate change impacts on law and policy in Florida. In: Florida's climate: changes, variations, \& impacts. Florida Climate Institute, Gainesville, pp 209-234

Sadri AM, Ukkusuri SV, Gladwin H (2017) The role of social networks and information sources on hurricane evacuation decision making. Natural Hazards Review 18(3):04017005

Scott M, Gallent N, Gkartzios M (2019) Planning rural futures. In: Scott M, Gallent N, Gkartzios M (eds) The Routledge companion to rural planning. Routledge, New York

Sultana F (2014) Gendering climate change: geographical insights. Prof Geogr 66(3):372-381

Sultana F (2017) Gender and water in a changing climate: challenges and opportunities. In: Water security across the gender divide, vol 93, 2nd edn. Springer, Cham, pp 17-33

Tall A (2019) Climate forecasting to serve communities in West Africa. Procedia Environ Sci $1: 421-431$

Umoh GS, Udo EJ, Solomon VA, Edet GE, Uwem CA, Okoro G, Bassey N, Akpan DO, Atairet E (2013) Adaptation to climate change. In: Agricultural ecosystems and gender dimensions. http:// www.xlibrispublishing.co.UK

UN (2018) Scoping paper for expert group meeting on climate variation adaptation. African minister conference on the environment 12th meeting of the expert group TBC 
United Nations Children's Fund (UNICEF) (2011) Situational analysis of children and women in Mongilia. UNICEF, Ukanbaatar

White I, Howe J (2012) Exploring the social impacts of flood risk and flooding in Scotland. Research findings no 32. Scottish Executive Social Research, Edinburgh

World Health Organization \& World Bank (2011) World report on disability. Geneva, Switzerland: World Health Organization

Open Access This chapter is licensed under the terms of the Creative Commons Attribution 4.0 International License (http://creativecommons.org/licenses/by/4.0/), which permits use, sharing, adaptation, distribution and reproduction in any medium or format, as long as you give appropriate credit to the original author(s) and the source, provide a link to the Creative Commons license and indicate if changes were made.

The images or other third party material in this chapter are included in the chapter's Creative Commons license, unless indicated otherwise in a credit line to the material. If material is not included in the chapter's Creative Commons license and your intended use is not permitted by statutory regulation or exceeds the permitted use, you will need to obtain permission directly from the copyright holder.

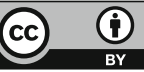

